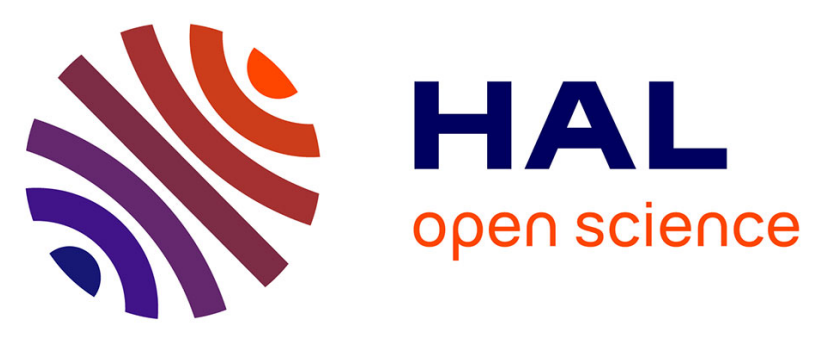

\title{
Plasticity of gene expression according to salinity in the testis of broodstock and F1 black-chinned tilapia, Sarotherodon melanotheron heudelotii
}

Jean-Christophe Avarre, Bruno Guinand, Rémi Dugué, Jacky Cosson, Marc Legendre, Jacques Panfili, Jean-Dominique Durand

\section{To cite this version:}

Jean-Christophe Avarre, Bruno Guinand, Rémi Dugué, Jacky Cosson, Marc Legendre, et al.. Plasticity of gene expression according to salinity in the testis of broodstock and F1 black-chinned tilapia, Sarotherodon melanotheron heudelotii. PeerJ, 2014, 2, 10.7717/peerj.702 . hal-01922667

\section{HAL Id: hal-01922667 \\ https://hal.science/hal-01922667}

Submitted on 19 Nov 2020

HAL is a multi-disciplinary open access archive for the deposit and dissemination of scientific research documents, whether they are published or not. The documents may come from teaching and research institutions in France or abroad, or from public or private research centers.
L'archive ouverte pluridisciplinaire HAL, est destinée au dépôt et à la diffusion de documents scientifiques de niveau recherche, publiés ou non, émanant des établissements d'enseignement et de recherche français ou étrangers, des laboratoires publics ou privés. 


\section{PeerJ}

Submitted 20 October 2014 Accepted 27 November 2014 Published 18 December 2014

Corresponding author

Jean-Christophe Avarre, jean-christophe.avarre@ird.fr

Academic editor

María Ángeles Esteban

Additional Information and Declarations can be found on page 15

DOI 10.7717/peerj.702

Copyright

2014 Avarre et al.

Distributed under

Creative Commons CC-BY 4.0

OPEN ACCESS

\section{Plasticity of gene expression according to salinity in the testis of broodstock and F1 black-chinned tilapia, Sarotherodon melanotheron heudelotii}

\author{
Jean-Christophe Avarre ${ }^{1}$, Bruno Guinand ${ }^{1}$, Rémi Dugué ${ }^{1}$, \\ Jacky Cosson $^{2}$, Marc Legendre ${ }^{1}$, Jacques Panfili ${ }^{3}$ and \\ Jean-Dominique Durand ${ }^{3}$ \\ ${ }^{1}$ Institut des Sciences de l'Evolution de Montpellier, UMR 226 IRD-CNRS-UM2, Montpellier, \\ France \\ ${ }^{2}$ Faculty of Fisheries and Protection of Waters, South Bohemian Research Center of Aquaculture \\ and Biodiversity of Hydrocenoses, Research Institute of Fish Culture and Hydrobiology, \\ University of South Bohemia in Ceske Budejovice, Vodňany, Czech Republic \\ ${ }^{3}$ Ecologie des Systèmes Marins Côtiers, UMR 5119 IRD-UM2-CNRS-IFREMER, Montpellier, \\ France
}

\section{ABSTRACT}

The black-chinned tilapia Sarotherodon melanotheron heudelotii Rüppell 1852 (Teleostei, Cichlidae) displays remarkable acclimation capacities. When exposed to drastic changes of salinity, which can be the case in its natural habitat, it develops quick physiological responses and keeps reproducing. The present study focused on the physiological impact of salinity on male reproductive capacities, using gene expression as a proxy of acclimation process. Two series of experimental fish were investigated: the first one was composed of fish maintained in freshwater for several generations and newly acclimated to salinities of 35 and 70, whereas the second one consisted of the descendants of the latter born and were raised under their native salinity. Expression patterns of 43 candidate genes previously identified from the testes of wild males was investigated in the three salinities and two generations. Twenty of them showed significant expression differences between salinities, and their predicted function revealed that most of them are involved in the osmotic tolerance of sperm cells and/or in the maintenance of sperm motility. A high level of expression variation was evidenced, especially for fish maintained in freshwater. In spite of this, gene expression patterns allowed the differentiation between fish raised in freshwater and those maintained in hypersaline water in both generations. Altogether, the results presented here suggest that this high variability of expression is likely to ensure the reproductive success of this species under varying salinities.

Subjects Aquaculture, Fisheries and Fish Science, Evolutionary Studies, Molecular Biology Keywords Male reproduction, Salinity, Gene expression, Acclimation, Fish

\section{INTRODUCTION}

The black-chinned tilapia, Sarotherodon melanotheron heudelotii Rüppell 1852 (Teleostei, Cichlidae), is a mouth-brooding fish that mainly occurs in estuarine and lagoon 
ecosystems of West Africa, but also sometimes in isolated, natural or artificial ponds. This species is an important local fish resource, accounting for a large part of catches in this area. Because of reduced freshwater input and the intense evaporation that has occurred over the last years (Pagès \& Citeau, 1990; Savenije \& Pages, 1992), it is regularly exposed to changes of salinity in its natural habitats. This led to physiological modifications of osmoregulation (Lorin-Nebel et al., 2012; Tine et al., 2011) and reproductive strategies (Gueye et al., 2012; Legendre et al., 2008; Panfili et al., 2004; Panfili et al., 2006).

Analysis of the gene expression patterns in the gills of this species evidenced a clear differentiation of sub-populations along the Sine Saloum estuary (Senegal) linked to the ambient salinity (Tine, Guinand \& Durand, 2012). It was also demonstrated that salinity induced phenotypic modifications of the mechanisms involved in the activation of sperm cell motility, one of the major indicators of male fitness (Fauvel, Suquet \& Cosson, 2010; Lahnsteiner et al., 1998). Indeed, the osmolality that enabled sperm activation in the black-chinned tilapia increased significantly with the salinity at which broodfish were maintained (Legendre et al., 2008). This finding was also recently reported for another estuarine species, Fundulus grandis (Tiersch \& Yang, 2012), indicating that increased knowledge in $S$. $m$. heudelotii could also benefit other euryhaline species.

Most of the studies focusing on the response of aquatic animals to alternative osmotic (Evans \& Somero, 2008; Larsen et al., 2007; Whitehead \& Crawford, 2006; Whitehead et al., 2011) or hypoxic (Gracey, 2007; Rathburn et al., 2013; Tiedke, Thiel \& Burmester, 2014) environments addressed this question through functional genomics of the gills and/or liver. Nevertheless, the fitness of individuals does not only rely on short-term, direct physiological responses to environmental challenges, but also on their capacity to produce viable gametes and offspring under a wide range of environmental conditions (Breckels \& Neff, 2013; Dorts et al., 2012). Salinity has been shown to significantly modify some reproductive traits such as length at first sexual maturity, fecundity and oocyte size in the wild (Diouf et al., 2009; Panfili et al., 2004; Panfili et al., 2006; Whiterod \& Walker, 2006). However, very few studies attempted to investigate how gene expression in gonads responded to salinity challenges, even though gametogenesis and gamete quality may be highly influenced by salinity (Alavi \& Cosson, 2006; Bobe \& Labbé, 2010; Cosson, 2004).

Using a high-throughput transcriptomic approach, Avarre et al. (2014) validated a de novo qPCR assay complying with the MIQE (Minimum Information for publication of Quantitative real-time PCR Experiments) guidelines (Bustin et al., 2009) for 43 candidate and 11 reference gene transcripts in the testes of mature males sampled in Senegal at locations displaying salinities of 40 and 95 . The aim of the present study was to examine the putative involvement of the expression pattern of these 43 candidate genes in the acclimation of male reproductive capacities to salinity changes over two generations. More specifically, it investigated (i) how transfer from low salinities (0) to high salinities (35 and 70) induced specific changes of gene expression in testes within a single parental generation, and (ii) if these variations persisted in the next generation $\left(\mathrm{F}_{1}\right)$. Two series of experimental fish were analyzed: the first one was composed of fish maintained in freshwater and newly acclimated to salinities of 35 and 70 ("transferred fish", T), whereas 
the second one consisted of the $F_{1}$ descendants of $T$ fish. These $F_{1}$ individuals were born and raised in each salinity condition ("born fish", B). Levels of gene expression were compared between the two generations in order to bring insights into the mechanisms that allow $S$. melanotheron males to respond to salinity changes without compromising the success of reproduction.

\section{MATERIAL AND METHODS}

\section{Fish samples}

The fish used in this study came from a single freshwater strain of Sarotherodon melanotheron heudelotii. They originated from a population of $\sim 50$ juveniles sampled in the Niayes (natural freshwater ponds) of Dakar (Senegal) and transferred to our facilities (Montpellier) nearly 15 years ago. Since then, fish have been reared in freshwater recirculation systems (i.e., in the same salinity as that of their natural environment). In order to minimize the loss of genetic diversity, 3-10 mate pairs were used to obtain a new generation, and one generation corresponded to approximately 18 months. Twelve mature males and twelve mature females (approximately 18 month old) from this pool (hereafter referred to as $\mathrm{T}$ ) were transferred to 3 independent water recirculation systems dedicated to a specific salinity (i.e., 0, 35 and 70). These salinities mimic fresh, saline and hypersaline waters in which $S$. melanotheron heudelotii may be frequently encountered in the wild. Because of technical limitations, experiments with higher water salinities were not implemented here. Each system comprised two breeding tanks (polyester tanks of $2.5 \mathrm{~m}$ length $\times 0.53 \mathrm{~m}$ width $\times 0.30 \mathrm{~m}$ depth). Water salinity was gradually increased at a rate of about 1 day $^{-1}$ by the addition of synthetic sea salt ("Instant Ocean", Aquarium system, Sarrebourg, France) until the target salinities of 35 and 70 were reached. Following a 5-week period of acclimation at the final salinities, fish were monitored for their reproductive behaviour over 18 weeks. Specifically, male reproductive success was assessed through the number of incubating males per tank (related to the number of available couples), the effective fertilization of incubated eggs and the viability of progenies. Finally, they were anaesthetized (Eugenol, $0.1 \mathrm{~mL} / \mathrm{L}$ ) and then killed by an overdose of anaesthetic (Eugenol, $0.5 \mathrm{~mL} / \mathrm{L}$ ) in ice (in accordance with the EU Directive 2010/63/EU) for dissection and testis collection. The body weight (Wb), fork length (FL) and gonad weight $(\mathrm{Wg})$ were recorded for each fish, and the gonadosomatic index (GSI) was calculated as follow: $\mathrm{Wg} / \mathrm{Wb} \times 100$. Condition factor $\mathrm{K}$ was also calculated, according to the standard formula $100 \times \mathrm{Wb} / \mathrm{FL}^{3}$. During this period, about 50 hatchlings from 6-8 spawning events per salinity were transferred to another series of tanks. They were grown at salinities of 0,35 and 70 until they were 9-11 months old, i.e., about 3 months after they became sexually mature. From these large pools of animals (referred to as B), 12 males and 12 females per salinity condition were randomly selected and transferred to the same breeding tanks used for T animals. Again, their reproductive activity was monitored for 18 consecutive weeks before they were processed for testis collection as indicated above. Testes were placed in RNA later (Ambion) overnight at $4{ }^{\circ} \mathrm{C}$ and then stored at $-20{ }^{\circ} \mathrm{C}$ until use. In total, testes from $33 \mathrm{~T}$ and $35 \mathrm{~B}$ fish were collected (Fig. 1). All the experimental 


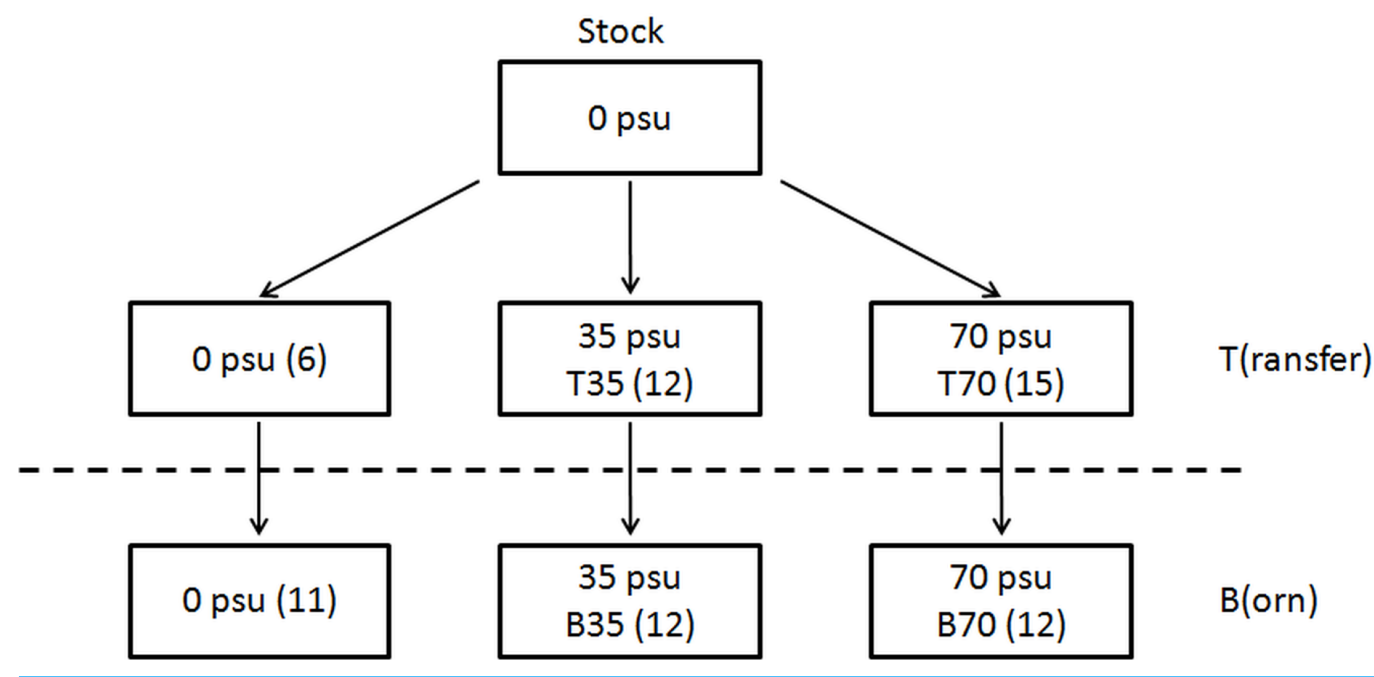

Figure 1 Origin of the 2 series of experimental animals considered in this study, which both originated from a single stock maintained in captivity in freshwater since $\sim 15$ years. $T$ animals result from a transfer from fish of this stock to the same (0) or to different salinity conditions (35 and 70). B animals represent first-generation male offspring from the reproduction of each category of $\mathrm{T}$ fish under their respective salinity conditions $(0,35$ or 70$)$. Number of $\mathrm{T}$ and $\mathrm{B}$ males collected from each salinity condition is reported in brackets.

procedures took place in our facilities in Montpellier, under the laboratory agreement for animal experimentation number A-34-172-24 and the author's personal authorization for animal experimentation number 34-188, both provided by the French government.

\section{RNA extraction and cDNA synthesis}

RNA was extracted with the Nucleospin-8 total RNA isolation kit (Macherey-Nagel). Fifteen to twenty mg of testis preserved in RNA later were weighed and transferred into $2 \mathrm{ml}$ tubes containing a $5 \mathrm{~mm}$ steel bead (Qiagen) as well as $360 \mu \mathrm{L}$ lysis buffer supplemented with $1 \% \beta$-mercaptoethanol (Sigma-Aldrich). Tissues were homogenized with a tissue lyzer (Qiagen) for $2 \mathrm{~min}$ at $50 \mathrm{~Hz}$. Tubes were then centrifuged for $5 \mathrm{~min}$ at full speed and the supernatants were transferred to new tubes and kept at $-20{ }^{\circ} \mathrm{C}$ overnight. RNA was extracted the following day according to the manufacturer's instructions, using a Janus automated workstation (Perkin Elmer), and eluted in $70 \mu \mathrm{L}$ RNase-free $\mathrm{H}_{2} \mathrm{O}$. In order to remove any trace of contaminating genomic DNA, RNA eluates were subjected to a second DNase treatment: a mix of $0.2 \mu \mathrm{L}$ of RNase-free DNase and $2 \mu \mathrm{L}$ of reaction buffer (Macherey-Nagel) was added to $20 \mu \mathrm{L}$ of each RNA eluate, and digestion was carried out for 15 min at $37^{\circ} \mathrm{C}$. RNA quantity was measured by UV spectrophotometry (Nanodrop 1000; Thermoscientific), and its integrity was verified by capillary electrophoresis (Agilent Bioanalyzer 2100). Each RNA sample was diluted to a concentration of $50 \mathrm{ng} \mu \mathrm{L}^{-1}$ in $\mathrm{H}_{2} \mathrm{O}$ and stored at $-80^{\circ} \mathrm{C}$.

Reverse transcription was performed with oligodT primers on $250 \mu \mathrm{g}$ RNA, using the transcriptor first strand cDNA synthesis kit (Roche). A template-primer mixture consisting of $250 \mu \mathrm{g}$ RNA and $2.5 \mu \mathrm{M}$ oligodT was denatured at $65^{\circ} \mathrm{C}$ for 10 -min and immedi- 
ately cooled on ice. The reaction (in $20 \mu \mathrm{L}$ final) was supplemented with reaction buffer (1X), dNTPs ( $1 \mathrm{mM}$ each), RNase inhibitor (20 U) and reverse transcriptase (10 U), incubated for $1 \mathrm{~h}$ at $50^{\circ} \mathrm{C}$, then heated for $5 \mathrm{~min}$ at $85^{\circ} \mathrm{C}$ and immediately cooled on ice. The resulting cDNAs were diluted 10 times with $180 \mu \mathrm{L} \mathrm{H}_{2} \mathrm{O}$ and stored at $-20^{\circ} \mathrm{C}$ until use.

\section{Gene sequence annotation}

The candidate and reference genes investigated here were identified using a highthroughput digital gene expression approach (Avarre et al., 2014). Their raw sequences can be found under SRA study accession number SRP022935, whereas the assembled sequences can be accessed through a freely accessible interactive database (http:// vmdiva-proto.ird.fr). Annotation of the corresponding sequences was therefore needed to infer their putative functions. This was realized with Blast2GO v2.6.6 (Conesa et al., 2005). Sequences were used as a query to search the non-redundant protein database available at the National Center for Biotechnology Information (www.ncbi.nlm.nih.gov) using the BlastX algorithm with an E-value cutoff set at $10^{-6}$. Sequences were then functionally annotated by mapping against gene ontology (GO) resources. Sequences that were not assigned any GO term were checked for conserved domains using the $\mathrm{CD}$-search tool (Marchler-Bauer \& Bryant, 2004). Likewise, sequences for which the number of BlastX hits was $<5$ were re-aligned using the BlastN algorithm, and their description was corrected when necessary.

\section{Gene expression analysis}

The expression of 43 candidate genes previously validated for their potential as being involved in testis response to salinity was analyzed by qPCR at the 3 salinities and for the 2 fish generations. PCR amplifications were carried out in 384-well plates with a LightCycler 480 (Roche) in a final volume of $6 \mu \mathrm{L}$ containing $3 \mu \mathrm{L}$ of SYBR Green I Master mix (Roche), $2 \mu \mathrm{L}$ of cDNA and $0.5 \mu \mathrm{M}$ of each primer (Avarre et al., 2014). Amplifications were performed in duplicate with an initial denaturation step of $10 \mathrm{~min}$ at $95^{\circ} \mathrm{C}$ followed by 40 cycles of denaturation at $95^{\circ} \mathrm{C}$ for $10 \mathrm{~s}$, annealing at $60^{\circ} \mathrm{C}$ for $10 \mathrm{~s}$ and elongation at $72^{\circ} \mathrm{C}$ for $10 \mathrm{~s}$. Amplifications were followed by a melting procedure, consisting of a brief denaturation at $95^{\circ} \mathrm{C}$ for $5 \mathrm{~s}$, a cooling step at $65^{\circ} \mathrm{C}$ for $1 \mathrm{~min}$ and a slow denaturation to $97^{\circ} \mathrm{C}$. Amplification products were validated by analyzing the shape of their corresponding melting curve and by measuring their size on agarose gel electrophoresis. For each given sample, all the genes were amplified simultaneously in the same 384-well plate, and each plate contained a no-template control for every primer pair. Cycle of quantification $(C q)$ values were calculated with the LightCycler software, using the second derivative method. Results were expressed as changes in relative expression according to the $2^{-\Delta \Delta C q}$ method (Pfaffl, 2001). Cq values were first corrected with the amplification efficiency of each primer pair according to the following equation: $C q_{\mathrm{E}=100 \%}=C q_{\mathrm{E}}(\log (1+\mathrm{E}) / \log (2))$, where $\mathrm{E}$ is the efficiency and $C q_{\mathrm{E}}$ the uncorrected $C q$ values. Then the corrected $C q$ s of each gene of interest were normalized $(\Delta C q)$ with the mean $C q$ of 4 validated reference genes (Avarre et al., 2014), and $\Delta C q$ values were related to the average $\Delta C q$ value of all samples. 


\section{Statistical analyses}

$\mathrm{T}$ and $\mathrm{B}$ animals maintained in freshwater were initially analyzed as 2 different groups; however, because they belonged to the same salinity treatment and were kept in the same conditions, they were also considered as one single group for statistical purposes. Comparison of the two situations showed that variations in gene expression followed the same trend, indicating that pooling did not mislead interpretation (not shown). All statistical analyses were performed with the GenEx Pro package (MultiD analyses, Sweden). The normality of data distribution was first verified for each series of samples using the Kolmogorov-Smirnov test. Since more than $90 \%$ of series turned out to be normally distributed, a one-way ANOVA test with a Tukey-Kramer's post-test was applied to infer significant differences between salinities, using a confidence level of 0.95 $(p<0.05) . P$-values were corrected for multiple testing using the false discovery rate (Benjamini \& Hochberg, 1995). Concurrently, expression levels were also compared by salinity pairs with a $t$-test, using the same confidence level. Finally, a principal component analysis (PCA) was also carried out on the two series of fish, according to the expression pattern of the investigated genes.

\section{RESULTS}

In spite of their age difference, average GSI for the two series of fish ( $\mathrm{T}$ and $\mathrm{B}$ ) were comparable, with mean $( \pm S D)$ values of $0.27 \pm 0.13$ and $0.26 \pm 0.12$ for $\mathrm{T}$ and $\mathrm{B}$ males, respectively. Condition factor calculated for each salinity group showed similar values, ranging between $1.99 \pm 0.11$ and $2.04 \pm 0.14$. Moreover, spermatozoa produced by the fish investigated in this study led to successful fertilization with viable offspring in all experimental conditions, indicating that salinity did not impair the ability of males to successfully reproduce.

\section{Differences in gene expression between salinities and generations}

A collective analysis of raw $C q$ values for the 43 candidate and 4 reference genes in the $33 \mathrm{~T}$ and 35 B fish with geNorm (Vandesompele et al., 2002) and NormFinder (Andersen, Jensen \& Ørntoft, 2004) software indicated that Contig_Tilapia_90_13722 (R1), Contig_Tilapia_90_7452 (R2), Contig_Tilapia_90_3058 (R3) and Transcript_AVA3_453 (R4) were the most stably expressed genes. This confirmed that these four genes were appropriate to use as reference in the present conditions, as was already demonstrated on wild fish (Avarre et al., 2014).

Among the 43 tested candidate genes, 20 showed significant variations between fish kept at different salinities in at least one of the 2 generations investigated in this study (Table 1). The number of genes that showed significant variations in their expression levels between salinities was higher in $\mathrm{T}(18)$ than in B (10) animals. The relative expression levels of these genes are displayed in Figs. 2 and 3. Generally, fold-changes in relative expression between the different salinity conditions were quite low, as the highest ratio was 3.86. Conversely, inter-individual variations among salinity groups were rather high. Interestingly, these variations were uppermost in fish kept in fresh water. Within each generation, the largest 
Table 1 List of genes showing significant differential expression between salinities in the two fish generations ( $T$ and $B$ ) and corresponding statistical values.

\begin{tabular}{|c|c|c|c|}
\hline \multirow[t]{2}{*}{ Original sequence name ${ }^{a}$} & \multirow[t]{2}{*}{ Gene \# ${ }^{b}$} & \multicolumn{2}{|c|}{ Corrected ANOVA $p$-values } \\
\hline & & $\mathrm{T}$ animals & $B$ animals \\
\hline Contig_Tilapia_90_6346 & 1 & $1.34 \mathrm{E}-03$ & $3.12 \mathrm{E}-05$ \\
\hline Contig_Tilapia_90_8891 & 2 & $8.76 \mathrm{E}-03$ & $7.60 \mathrm{E}-02$ \\
\hline Contig_Tilapia_90_947 & 3 & $1.46 \mathrm{E}-01$ & $6.70 \mathrm{E}-04$ \\
\hline Contig_Tilapia_90_6938 & 4 & $1.29 \mathrm{E}-02$ & $1.97 \mathrm{E}-03$ \\
\hline Contig_Tilapia_90_21432 & 5 & $3.84 \mathrm{E}-01$ & $3.17 \mathrm{E}-03$ \\
\hline Contig_Tilapia_90_1393 & 6 & $7.53 \mathrm{E}-05$ & $7.67 \mathrm{E}-01$ \\
\hline Contig_Tilapia_90_10643 & 7 & $3.13 \mathrm{E}-02$ & $1.06 \mathrm{E}-03$ \\
\hline Transcript_AVA3_33497 & 8 & $1.28 \mathrm{E}-05$ & $1.60 \mathrm{E}-03$ \\
\hline Transcript_AVA1_24409 & 9 & $2.02 \mathrm{E}-04$ & $1.75 \mathrm{E}-02$ \\
\hline Contig_Tilapia_90_26617 & 10 & $1.29 \mathrm{E}-02$ & $1.03 \mathrm{E}-02$ \\
\hline Contig_Tilapia_90_2414 & 11 & $3.38 \mathrm{E}-02$ & $3.35 \mathrm{E}-01$ \\
\hline Contig_Tilapia_90_2253 & 12 & $1.29 \mathrm{E}-02$ & $1.08 \mathrm{E}-01$ \\
\hline Contig_Tilapia_90_2777 & 13 & $1.29 \mathrm{E}-02$ & $9.62 \mathrm{E}-01$ \\
\hline Contig_Tilapia_90_8343 & 14 & $1.05 \mathrm{E}-02$ & $9.73 \mathrm{E}-01$ \\
\hline Transcript_AVA1_58357 & 15 & $3.38 \mathrm{E}-02$ & $5.67 \mathrm{E}-01$ \\
\hline Contig_Tilapia_90_26561 & 16 & $1.34 \mathrm{E}-03$ & $1.07 \mathrm{E}-02$ \\
\hline Contig_Tilapia_90_27008 & 17 & $7.76 \mathrm{E}-04$ & $1.08 \mathrm{E}-01$ \\
\hline Contig_Tilapia_90_1736 & 18 & $1.32 \mathrm{E}-02$ & $1.08 \mathrm{E}-01$ \\
\hline Contig_Tilapia_90_7359 & 19 & $1.54 \mathrm{E}-04$ & $2.65 \mathrm{E}-02$ \\
\hline Contig_Tilapia_90_2321 & 20 & $7.53 \mathrm{E}-05$ & $3.35 \mathrm{E}-01$ \\
\hline
\end{tabular}

Notes.

${ }^{\text {a }}$ Names of the sequences as they appear at http://vmdiva-proto.ird.fr.

b This gene numbering is used in Table 2, Figs. 2 and 3 and throughout the text in order to facilitate reading.

differences were observed between the most extreme salinities, i.e., between 0 and 70, and to a lesser extent between 0 and 35, as indicated by Tukey-Kramer pairwise comparisons. In $\mathrm{T}$ fish, the number of genes showing significant differences was 11 between fresh and seawater, 15 between fresh and hypersaline water and 2 between saline and hypersaline water. In B fish, these numbers amounted to 5, 11 and 2, respectively. Likewise, the largest fold-change differences were also observed between salinities 0 and 70 for the two series of animals. Overall, directions of expression differences between salinities were comparable in both generations.

Results of the PCA, based on the expression pattern of the 20 investigated genes, are displayed in Fig. 4. The two first PC axes accounted for $87.20 \%$ and $5.40 \%$ of variation. Because the variation explained by the second axis accounted for approximately 17 times less than the first one, an ANOVA with a Tukey-Kramer's pairwise comparison was performed on the PC scores of the first axis only. It revealed that freshwater males could be significantly differentiated from T35 $(P=0.024)$, T70 $(P=0.0015)$ and B70 $(P=0.0004)$ animals, but not from B35 ones $(P>0.05)$. Moreover, there were no significant differences between T35 and B35 animals or between T70 and B70 animals $(P>0.05)$. 


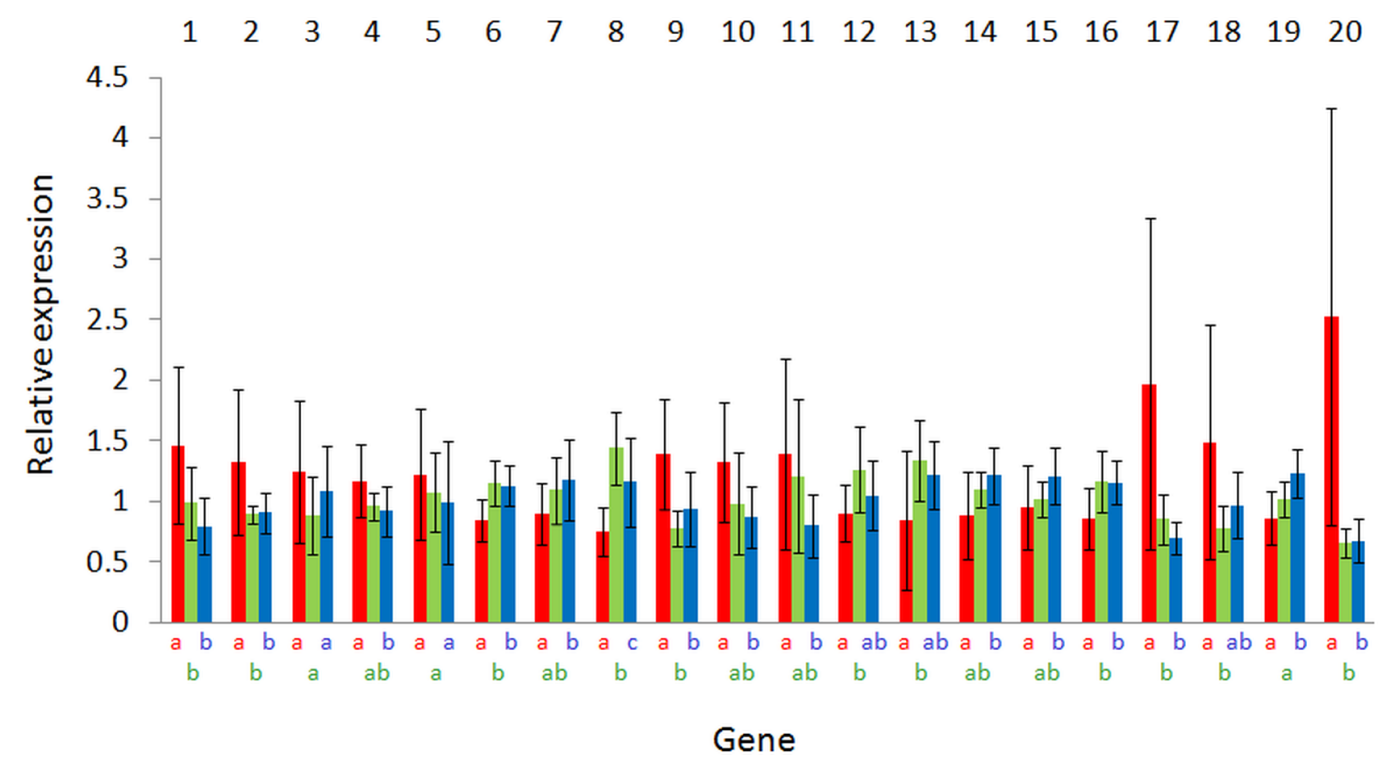

Figure 2 Expression variations according to salinity of the 20 significant genes for $\mathrm{T}$ animals. Values are expressed as relative expression \pm SD. Original sequence names may be found in Table 1 . Bars are colored according to the salinity condition (red, freshwater; green, seawater; blue, hypersaline water). Identical letters indicate no significant differences (according to a Tukey-Kramer's post-ANOVA test) between salinities.

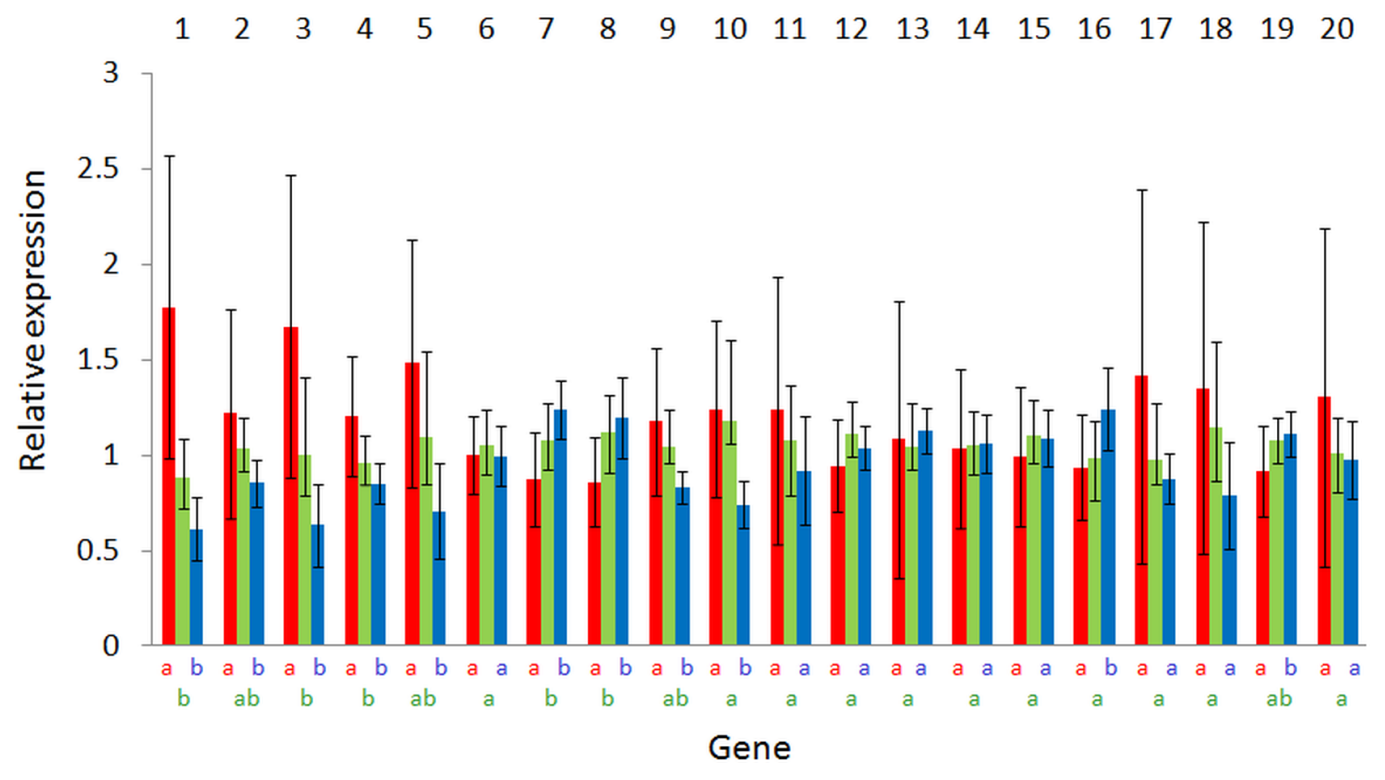

Figure 3 Expression variations according to salinity of the $\mathbf{2 0}$ significant genes for $\mathbf{B}$ animals. Values are expressed as relative expression $\pm \mathrm{SD}$. Original sequence names may be found in Table 1 . Bars are colored according to the salinity condition (red, freshwater; green, seawater; blue, hypersaline water). Identical letters indicate no significant differences (according to a Tukey-Kramer's post-ANOVA test) between salinities. 


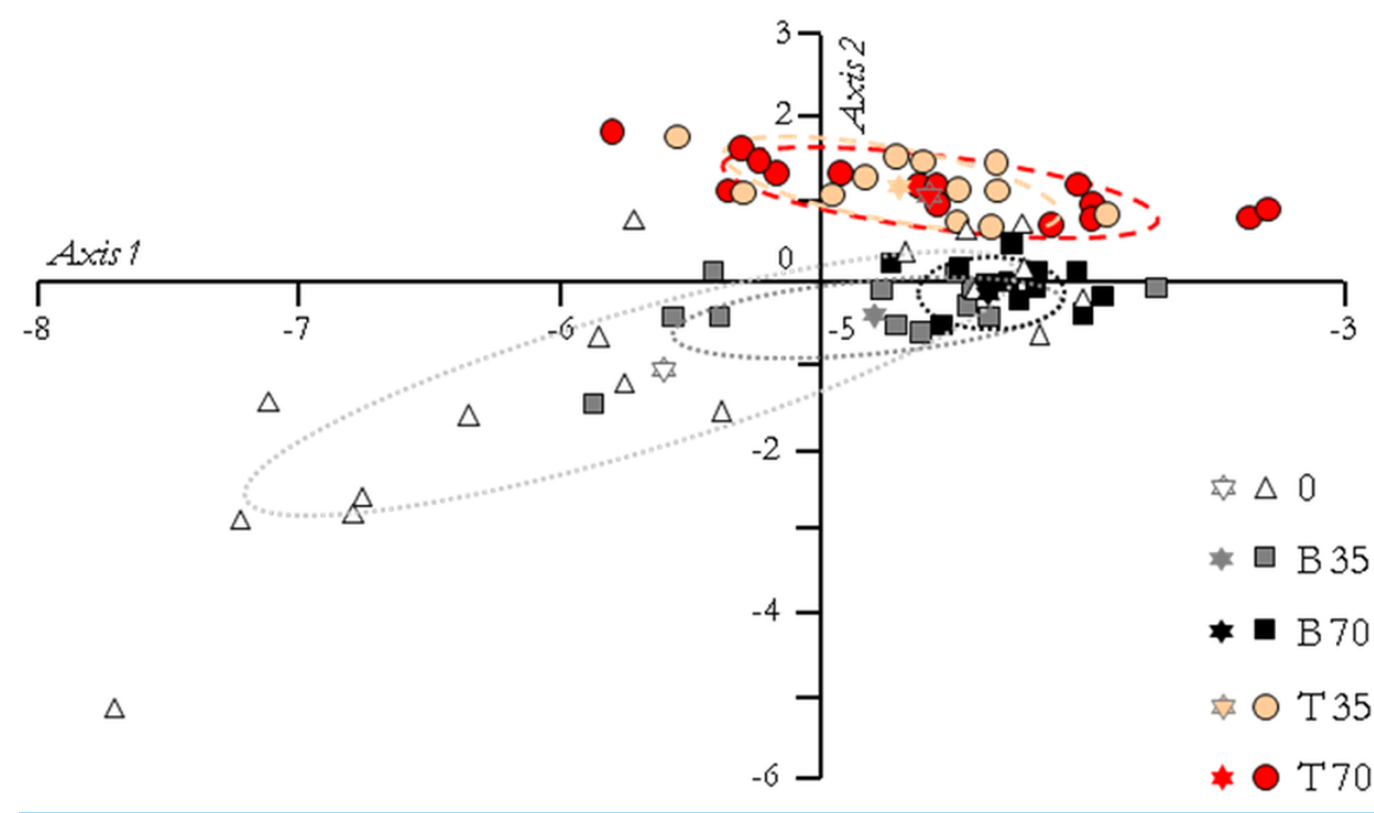

Figure 4 Principal component analysis of the fish groups according to their gene expression pattern. The first axis accounted for $87.20 \%$ of the total variance and the second axis for $5.40 \%$. The ellipses include $95 \%$ of the variance within each group, and the stars represent the gravity center of each ellipse. According to a Tukey-Kramer's pairwise comparison test performed on the principal component scores of the first axis, freshwater animals (group 0 ) are significantly differentiated from those of groups T35 $(P=0.024)$, T70 $(P=0.0015)$ and B70 $(P=0.0004)$.

\section{Predicted function of the differentially expressed and reference genes}

Except for Contig_Tilapia_90_2321 which returned no significant blastX hit and Transcript_AVA3_33497 which matched a hypothetical protein, all 24 genes could be attributed to either a known or a predicted function with rather low E-values. Among these, 21 could be assigned at least one GO description (Table 2). The list contains proteins for which a putative role in spermatogenesis has already been proven in other organisms (MORC family CW-type zinc finger 2 protein, $28 \mathrm{kDa}$ heat- and acid-stable phosphoprotein, seminal plasma glycoprotein), as well as proteins involved in energy metabolism (NADH dehydrogenases, phosphatase), in stress response and osmoregulation (heat shock proteins, sodium potassium ATPase), or in axonemal activity (calcium-binding protein, beta-tubulin). The predicted function of the 23 remaining genes, which did not show any significant variations according to salinity, is displayed in Table S1.

\section{DISCUSSION}

This study aimed to analyze how mature males originating from a single freshwater population responded to transfer in saline (salinity 35) or hypersaline (salinity 70) water, and how $F_{1}$ individuals born in these new environments expressed the same genes. Salinity changes were shown to noticeably modify the life-histories and reproductive strategies of populations (Gueye et al., 2012; Legendre et al., 2008; Panfili et al., 2004; Panfili et al., 2006), 
Table 2 Annotation features of the 20 responsive and 4 reference genes.

\begin{tabular}{|c|c|c|c|c|c|c|}
\hline Gene \# & $\begin{array}{l}\text { Sequence } \\
\text { length }(\mathrm{nt})\end{array}$ & $\begin{array}{l}\text { \#BlastX } \\
\text { hits }^{\text {a }}\end{array}$ & $\begin{array}{l}\text { Protein } \\
\text { description }^{b}\end{array}$ & $\begin{array}{l}\text { Best hit } \\
\text { accession }\end{array}$ & E-Value & $\begin{array}{l}\text { \#GO } \\
\text { terms }\end{array}$ \\
\hline \multicolumn{7}{|c|}{ Differentially expressed genes } \\
\hline 1 & 353 & 16 & $\begin{array}{l}\text { PREDICTED: type- } 4 \text { ice-structuring } \\
\text { protein-like }\end{array}$ & XP_004549213 & $1.06533 \mathrm{E}-61$ & 2 \\
\hline 2 & 584 & 20 & $\begin{array}{l}\text { PREDICTED: tubulin-specific } \\
\text { chaperone A-like }\end{array}$ & XP_003455155 & $4.68328 \mathrm{E}-50$ & 5 \\
\hline 3 & 524 & 20 & $\begin{array}{l}\text { sodium/potassium-transporting } \\
\text { ATPase alpha-1 subunit }\end{array}$ & AGO02179 & $4.12826 \mathrm{E}-87$ & 20 \\
\hline 4 & 289 & 20 & $\begin{array}{l}\text { Serine/threonine-protein } \\
\text { phosphatase } 6 \text { catalytic subunit }\end{array}$ & ELW48549 & $1.44788 \mathrm{E}-46$ & 6 \\
\hline 5 & 164 & 20 & $\begin{array}{l}\text { PREDICTED: sperm plasma } \\
\text { glycoprotein } 120\end{array}$ & XP_004574936 & $4.12231 \mathrm{E}-23$ & 0 \\
\hline 6 & 849 & 20 & $\begin{array}{l}\text { PREDICTED: proteasome } \\
\text { subunit alpha type-5-like }\end{array}$ & XP_003441568 & $8.42686 \mathrm{E}-175$ & 19 \\
\hline 7 & 459 & 20 & PREDICTED: neuroserpin-like & XP_004561427 & $1.13288 \mathrm{E}-76$ & 4 \\
\hline 8 & 177 & 1 & Hypothetical protein & XP_004563130 & $5.19086 \mathrm{E}-18$ & 0 \\
\hline 9 & 260 & 20 & $\begin{array}{l}\text { PREDICTED: NADH dehydrogenase } \\
\text { [ubiquinone] } 1 \text { beta subcomplex } \\
\text { subunit 3-like }\end{array}$ & XP_003457472 & $8.68852 \mathrm{E}-26$ & 2 \\
\hline 10 & 179 & 20 & NADH dehydrogenase subunit 1 & ADR10264 & $3.32857 \mathrm{E}-21$ & 4 \\
\hline 11 & 604 & 20 & $\begin{array}{l}\text { PREDICTED: hypoxia-induced gene } \\
\text { domain family member 1A-like }\end{array}$ & XP_003438136 & $4.44514 \mathrm{E}-47$ & 1 \\
\hline 12 & 545 & 20 & Heat shock protein 90 & CAX33858 & 8.51839E-92 & 34 \\
\hline 13 & 1,010 & 20 & Heat shock protein 70 & ACI42865 & 0.0 & 3 \\
\hline 14 & 506 & 20 & $\begin{array}{l}\text { PREDICTED: glutathione } \\
\text { S-transferase theta-1-like }\end{array}$ & XP_004572434 & $1.57519 \mathrm{E}-28$ & 1 \\
\hline 15 & 321 & 20 & $\begin{array}{l}\text { PREDICTED: calcium-binding } \\
\text { protein 39-like isoform X1 }\end{array}$ & XP_004573664 & $6.54477 \mathrm{E}-61$ & 8 \\
\hline 16 & 230 & 20 & Beta tubulin & BAD11697 & $7.71535 \mathrm{E}-48$ & 7 \\
\hline 17 & 313 & 20 & $\begin{array}{l}\text { PREDICTED: MORC family CW-type } \\
\text { zinc finger protein } 2 \mathrm{~A} \text {-like }\end{array}$ & XP_004544577 & $5.08988 \mathrm{E}-31$ & 2 \\
\hline 18 & 1,105 & 20 & PREDICTED: nucleolar protein 56-like & XP_004545283 & $3.59979 \mathrm{E}-151$ & 8 \\
\hline 19 & 465 & 20 & $\begin{array}{l}\text { PREDICTED: } 28 \mathrm{kDa} \text { heat- and } \\
\text { acid-stable phosphoprotein-like }\end{array}$ & XP_003443172 & $4.92124 \mathrm{E}-54$ & 4 \\
\hline 20 & 512 & 0 & - & - & - & 0 \\
\hline \multicolumn{7}{|c|}{ Reference genes } \\
\hline $\mathrm{R} 1$ & 291 & 20 & $\begin{array}{l}\text { PREDICTED: NADH dehydrogenase } \\
\text { [ubiquinone] flavoprotein } 1 \text {, } \\
\text { mitochondrial-like }\end{array}$ & XP_003452502 & $5.14723 \mathrm{E}-58$ & 8 \\
\hline R2 & 299 & 20 & $\begin{array}{l}\text { PREDICTED: NADH dehydrogenase } \\
\text { [ubiquinone] } 1 \text { alpha subcomplex } \\
\text { subunit } 10, \text { mitochondrial-like }\end{array}$ & XP_004571622 & $7.27748 \mathrm{E}-52$ & 6 \\
\hline R3 & 265 & 20 & PREDICTED: tubulin beta- $4 \mathrm{~B}$ chain & XP_004005609 & $1.57111 \mathrm{E}-59$ & 21 \\
\hline R4 & 323 & 20 & $\begin{array}{l}\text { PREDICTED: cytochrome } \\
\text { c oxidase subunit } 6 \mathrm{C}-1 \text {-like }\end{array}$ & XP_003451899 & $3.40807 \mathrm{E}-36$ & 6 \\
\hline
\end{tabular}

\section{Notes.}

${ }^{\mathrm{a}}$ The number of BlastX hits was limited to 20 .

$\mathrm{b}$ According to the best blast hit. 
and to impact their osmoregulatory capacities (Lorin-Nebel et al., 2012; Tine, Guinand \& Durand, 2012) and their stress response (Tine et al., 2010). Nevertheless, gene expression variation in reproductive organs like testes was never investigated, although they are necessary to the preservation of male fitness and contribute to the demographic features of populations. Previous results have shown that the salinity of the water under which fish were raised had a major effect on sperm characteristics and on the conditions for the activation of spermatozoa motility. Particularly, higher osmolality and higher concentrations of extracellular calcium were required for the activation of spermatozoa in fish maintained in saline/hypersaline water (Legendre et al., 2008 and M Legendre, 2014, unpublished data). The precise mechanisms, and especially the molecular basis behind these physiological adaptations, still need further investigations. However, as intra-testicular spermatozoa and other testicular cell types are particularly difficult to separate, and the quantification of gene expression for each single cell type difficult to reach, studying gene expression variation at the testis level is a necessary step for deciphering the genes involved in salinity acclimation. Physiological changes related to environmental salinity were observed not only at the spermatozoa level (motility activation), but also at the gonad level (e.g., ionic content and osmolarity of the seminal fluid involved in the protection of spermatozoa during storage in the reproductive system) (M Legendre, 2014, unpublished data), indicating that a tissue level approach is necessary.

Global expression patterns of the 20 genes distinguished fish that only experienced freshwater from their counterparts acclimated to saline and hypersaline conditions (T35 and T70). This reflected a shift-i.e., a plastic response-in mean levels of gene expression from a standard freshwater environment to a new environment, with no significant differences in global gene expression patterns between T35 and T70 males. Among B animals (i.e., born in a specific salinity), gene expression patterns were found significantly different only between freshwater and B70 males. Inter-individual variation in mRNA levels was found highest for $\mathrm{T}$ and $\mathrm{B}$ fish maintained in freshwater, i.e., the only animals that did not undergo any environmental change for many generations. Concurrently, inter-individual variation in gene expression was around twice lower in T35, B35 and T70 males, and 3 times lower in B70 fish. Elevated inter-individual variations in mRNA levels have been proposed as a possible source of variation to enable future evolution in reaction to rapid environmental changes (Aubin-Horth et al., 2005; Oleksiak, Churchill \& Crawford, 2002; Whitehead \& Crawford, 2005; Whitehead \& Crawford, 2006), since production of better adapted protein orthologs does not fit such short time-scales (Hofmann \& Todgham, 2010). By contrast with gene expression levels, no differences in fertilization capabilities were observed between all investigated fish. If the salinity increase induced a shift in the osmolarity at which sperm cells were activated (not shown), it did not yet affect sperm motility itself, and spermatozoa produced by all the fish led to successful fertilization with viable offspring in all experimental situations. This indicates that salinity changes and salinity itself did not impair the ability of males to reproduce successfully. Combined these findings suggest that the genes investigated here are involved in the mechanisms of acclimation to salinity. They also support the hypothesis that naturally-occurring 
expression variation contributes to the phenotypic plasticity of male black-chinned tilapia, which ensures its reproductive success under varying salinities. Nevertheless, this plasticity may differ between $\mathrm{T}$ and $\mathrm{B}$ fish. Indeed, $\mathrm{T}$ fish demonstrated an ability to respond to a punctual, context-dependent change in environmental conditions after being raised in a common environment, a process known as phenotypic flexibility (Piersma \& Drent, 2003). In contrast, B fish 'accomodated' their respective saline environment since hatching, and differences in gene expression across treatments might partly originate from the developmental component of gene expression plasticity (West-Eberhard, 2003). The present experimental design does not permit us to conclude whether the differences found between $\mathrm{T}$ and $\mathrm{B}$ animals (in terms of gene expression) are due to phenotypic flexibility itself or to the co-occurrence of both types of plasticity. Detailed studies of these two components of plasticity warrant further investigations into the black-chinned tilapia.

Among the 20 genes showing differential expression in the testes, many encode proteins that have a link with the general oxidation-reduction level of sperm cells, and/or participate to plasma membrane channel activity through differential regulation of ion content. Both activities play an important role in the osmotic tolerance of sperm cells (Morita et al., 2011) and in the maintenance of sperm motility in fish (Alavi \& Cosson, 2006). The potential involvement of some of these genes is discussed below.

Among the largest variations in gene expression that were observed, gene 1 encodes a protein homologous to type-IV ice-structuring protein, also known as antifreeze protein type-IV (AFPIV). The AFPIV has already been reported in many fishes from cold, temperate and warm waters (Lee et al., 2011), and its role is still subject to question. It was indeed shown to have actual antifreeze ability. However, its low plasma level measured in the longhorn sculpin (Myoxocephalus octodecimspinosis) suggests another function for this protein, such as a role in lipid transport due to its close structure relatedness with that of fish apolipoproteins (Gauthier et al., 2008). Recently, AFPIV was shown to be abundantly synthesized in ovaries of the Atlantic cod (Gadus morhua), especially during late stages of vitellogenesis, and was proposed to be involved in lipid transport and/or metabolism (Breton et al., 2012), in spite of a proven low concentration in the blood of adults (Gauthier et al., 2008). Finally, expression of AFPIV was also demonstrated in embryos of the gibel carp (Carassius auratus gibelio), and the authors proposed a potential role in the embryonic patterning (Liu, Zhai \& Gui, 2009). Beyond their role in fish, it is known that antifreeze proteins participate to the osmotic resistance of spermatozoa by reducing mechanical stress to the cell membrane. They are hence often used in sperm cryopreservation (Prathalingam et al., 2006). Genes or more general factors regulating osmolality and ion content are central to sperm motility (Cosson et al., 2008). In both T and B fish, expression of gene 1 significantly decreased with the salinity to which tilapia fish specimens were exposed. Experimental evidence is now required to elucidate the potential role of an antifreeze type IV-related protein in the adaptation to salinity, especially with regard to male gonadic activity and fertility. This is the first time that expression of an AFPIV is reported to occur in testes. 
If the expression of the $\mathrm{Na}+/ \mathrm{K}+$ ATPase (NKA) gene has been extensively studied in the gills of fish exposed to different salinities (Havird, Henry \& Wilson, 2013), including S. melanotheron (Lorin-Nebel et al., 2012; Tine et al., 2008; Tine, Guinand \& Durand, 2012), this is only the first report of its expression in the testes (gene 3). In gills, NKA plays an essential role in osmoregulation through branchial ionocytes to actively uptake/excrete ions from/to environmental water, respectively. Since testes have no ionocytes, it is likely that NKA plays other roles in the male gonads, and this requires further investigation. Sequence 4 matches a portion of the catalytic subunit of a serine-threonine protein phosphatase. A modulatory role of serine-threonine protein phosphatase in osmoregulation has been demonstrated in fish (Marshall, Ossum \& Hoffmann, 2005), but details are scarce and the mechanisms still poorly explained, most likely because of the myriad reactions controlled by serine-threonine protein phosphatases (Shi, 2009). The involvement of several serine-threonine protein phosphatases in the regulation of sperm motility was recently demonstrated in humans (Fardilha et al., 2013); this research has to be extended to fish. Sequence 5 is similar to that of a seminal plasma glycoprotein that contains both a partial von Willebrand factor type $\mathrm{D}$ domain and a zona pellucida (ZP) domain. This high molecular weight glyco-protein was shown to have a sperm-binding activity and a sperm-immobilizing activity (Mochida et al., 2002).

The predicted function of gene 15 points to a possible calcium-binding activity. A significant raise of its abundance was observed with salinity in $\mathrm{T}$ animals, suggesting an increase of $\mathrm{Ca}^{2+}$ metabolism in the testes of fish exposed to higher salinities. Earlier studies on another euryhaline tilapia, Oreochromis mossambicus, suggested that acclimation of sperm motility to salinity was associated with a modulation of the $\mathrm{Ca}^{2+}$ flow in order to increase its intracellular concentration (Morita, Takemura \& Okuno, 2004). More recent studies on the black-chinned tilapia showed that the osmolality that enabled sperm activation increased significantly with the salinity at which broodfish were maintained. It was also found that increasing amounts of calcium in the sperm activation medium were needed to initiate sperm motility as a function of fish rearing salinity (Legendre et al., 2008).

Sequence 16 matches a beta-tubulin, which involvement in the flagellar motility, especially through post-translational modifications, has been shown for a wide range of organisms (Huitorel et al., 1999). The description of gene 17 matches a MORC family CW-type zinc $(\mathrm{Zn})$ finger protein, which absence was first shown to trigger the stop of spermatogenesis in mice (Watson et al., 1998). Zinc is a trace element essential to reproduction in both sexes of numerous mammalian species including humans (Bedwal \& Bahuguna, 1994). Its involvement in spermatogenesis was recently shown in the Japanese eel (Anguilla japonica) by activating Zn-finger proteins and modulating transcription factor genes containing Zn-finger motifs (Yamaguchi et al., 2009). It allows for the regulation of mitotic cell proliferation and meiosis, the activation/inactivation of sperm motility, and may also affect the regulation of steroid hormone receptors including androgens (Yamaguchi et al., 2009).

Among the 24 (reference and differentially expressed) genes analyzed in this study, four encode predicted NADH dehydrogenase subunits: two of them showed differential 
expression between salinities (genes 9 and 10), whereas the other two were used as reference (R1 and R2). Expression of NADH dehydrogenase was already demonstrated to significantly vary with salinity in the gills of the black-chinned tilapia (Tine et al., 2010; Tine et al., 2008; Tine, Guinand \& Durand, 2012), but transcripts were not annotated precisely at that time. The two differentially regulated transcripts found in this study correspond to subunits ND1 and NDUFB3/B12, whereas the two sequences used as reference correspond to subunits NDUFV1 and NDUFA10. All of these NADH dehydrogenase subunits are part of a complicated multiprotein complex located in the inner mitochondrial membrane, the NADH:ubiquinone oxidoreductase (complex I). It plays a central role in oxidative phosphorylation and its main function is the transport of electrons by oxidation of $\mathrm{NADH}$ followed by reduction of ubiquinone, which is accompanied by the translocation of protons from the mitochondrial matrix to the inter-membrane space (Loeffen et al., 1998). In humans, correlations between sperm quality or sperm motility and mitochondrial activities including oxidative phosphorylation have been known for some time (Piomboni et al., 2012; Ruiz-Pesini et al., 1998). Complex I is composed of 45 different subunits, regulated by both nuclear and mitochondrial genomes (Lazarou et al., 2009). It is therefore not surprising that different subunits may be subjected to differing regulation pathways, depending on available substrates and on the physico-chemical conditions in which they operate, as reported in humans (Piomboni et al., 2012). This was recently shown in fish by a study analyzing the transcriptional regulation during the ovarian development of the Senegalese sole (Solea senegalensis) (Tingaud-Sequeira et al., 2009), but data on male-specific tissues such as testes are lacking. Variations in complex I activity have been reported in many species, especially in the case of altered environments, and a reduction of its activity with water temperature was recently shown in Fundulus heteroclitus (Loftus $\approx$ Crawford, 2013). In the present study, expression of the two above-mentioned subunits significantly decreased with salinity. This differential expression could be related to the link of complex I with reactive oxygen species (ROS) (Maranzana et al., 2013), which are known to be involved in the control of sperm motility, both in mammals (de Lamirande et al., 1997) and fish (Shaliutina et al., 2014). Indeed, a recent study pointed out a relationship between the oxidation-reduction level and the phosphorylation status of an $18-\mathrm{kDa}$ superoxide anion scavenger protein in the sperm cells of Oreochromis mossambicus, and showed that ROS-dependent mechanisms contributed to the osmotic tolerance of this other euryhaline tilapia (Morita et al., 2011).

\section{CONCLUSION}

The present study enabled the identification of 20 candidate genes likely involved in the acclimation to salinity changes of the reproductive physiology of Sarotherodon melanotheron heudelotii. It evidenced the potential role of unexpected transcripts (such as that encoding an antifreeze protein type-IV), and supported the hypothesis that elevated variations in gene expression may contribute to the remarkable plasticity of this species. The relative contribution of phenotypic flexibility and developmental plasticity needs 
to be investigated in more detail, in order to gain further understanding on the fitness consequences of such changes in testis gene expression.

\section{ACKNOWLEDGEMENT}

We are very grateful to Mr. Christophe Cochet for his strong involvement in the maintenance of fish welfare. This is publication IRD-DIVA-ISEM-2014-190.

\section{ADDITIONAL INFORMATION AND DECLARATIONS}

\section{Funding}

This study was supported by an INSU (Institut National des Sciences de l'Univers)EC2CO (Ecosphère Continentale et Côtière) grant (2010-2012). Jean-Christophe Avarre received funding from GACR P502/12/1973, LD14119, CENAKVA CZ.1.05/2.1.00/01.0024 and LO1205 and also from the national CZ COST project as part of the International COST action "Aquagamete", number LD14119. The results of the project LO1205 were obtained with financial support from the MEYS of the CR under the NPU I program. The funders had no role in study design, data collection and analysis, decision to publish, or preparation of the manuscript.

\section{Grant Disclosures}

The following grant information was disclosed by the authors:

INSU (Institut National des Sciences de l'Univers)_EC2CO (Ecosphère Continentale et Côtière): (2010-2012).

GACR: P502/12/1973, LD14119.

CENAKVA: CZ.1.05/2.1.00/01.0024, LO1205.

National CZ COST project: LD14119.

\section{Competing Interests}

The authors declare there are no competing interests.

\section{Author Contributions}

- Jean-Christophe Avarre conceived and designed the experiments, performed the experiments, analyzed the data, contributed reagents/materials/analysis tools, wrote the paper, prepared figures and/or tables, reviewed drafts of the paper.

- Bruno Guinand analyzed the data, wrote the paper, prepared figures and/or tables, reviewed drafts of the paper.

- Rémi Dugué performed the experiments, reviewed drafts of the paper.

- Jacky Cosson, Marc Legendre and Jacques Panfili performed the experiments, contributed reagents/materials/analysis tools, reviewed drafts of the paper.

- Jean-Dominique Durand conceived and designed the experiments, wrote the paper, reviewed drafts of the paper. 


\section{Animal Ethics}

The following information was supplied relating to ethical approvals (i.e., approving body and any reference numbers):

All the experimental procedures took place in our facilities in Montpellier, under the laboratory agreement for animal experimentation number A-34-172-24 and the author's personal authorization for animal experimentation number 34-188, both delivered by the French government.

\section{Data Deposition}

The following information was supplied regarding the deposition of related data:

Sequence Read Archive \#SRP022935 "Sarotherodon melanotheron heudelotii RNAseq".

\section{Supplemental Information}

Supplemental information for this article can be found online at http://dx.doi.org/ 10.7717/peerj.702\#supplemental-information.

\section{REFERENCES}

Alavi SMH, Cosson J. 2006. Sperm motility in fishes. (II) Effects of ions and osmolality: a review. Cell Biology International 30:1-14 DOI 10.1016/j.cellbi.2005.06.004.

Andersen CL, Jensen JL, Ørntoft TF. 2004. Normalization of real-time quantitative reverse transcription-PCR data: a model-based variance estimation approach to identify genes suited for normalization, applied to bladder and colon cancer data sets. Cancer Research 64:5245-5250 DOI 10.1158/0008-5472.CAN-04-0496.

Aubin-Horth N, Landry CR, Letcher BH, Hofmann HA. 2005. Alternative life histories shape brain gene expression profiles in males of the same population. Proceedings of the Royal Society B: Biological Sciences 272:1655-1662 DOI 10.1098/rspb.2005.3125.

Avarre JC, Dugue R, Alonso P, Diombokho A, Joffrois C, Faivre N, Cochet C, Durand JD. 2014. Analysis of the black-chinned tilapia Sarotherodon melanotheron heudelotii reproducing under a wide range of salinities: from RNA-seq to candidate genes. Molecular Ecology Resources 14:139-149 DOI 10.1111/1755-0998.12148.

Bedwal RS, Bahuguna A. 1994. Zinc, copper and selenium in reproduction. Experientia 50:626-640 DOI 10.1007/BF01952862.

Benjamini Y, Hochberg Y. 1995. Controlling the false discovery rate-a practical and powerful approach to multiple testing. Journal of the Royal Statistical Society Series B-Methodological 57:289-300.

Bobe J, Labbé C. 2010. Egg and sperm quality in fish. General and Comparative Endocrinology 165:535-548 DOI 10.1016/j.ygcen.2009.02.011.

Breckels RD, Neff BD. 2013. The effects of elevated temperature on the sexual traits, immunology and survivorship of a tropical ectotherm. Journal of Experimental Biology 216:2658-2664 DOI 10.1242/jeb.084962.

Breton TS, Anderson JL, Goetz FW, Berlinsky DL. 2012. Identification of ovarian gene expression patterns during vitellogenesis in Atlantic cod (Gadus morhua). General and Comparative Endocrinology 179:296-304 DOI 10.1016/j.ygcen.2012.09.003. 
Bustin SA, Benes V, Garson JA, Hellemans J, Huggett J, Kubista M, Mueller R, Nolan T, Pfaffl MW, Shipley GL, Vandesompele J, Wittwer CT. 2009. The MIQE guidelines: minimum information for publication of quantitative real-time PCR experiments. Clinical Chemistry 55:611-622 DOI 10.1373/clinchem.2008.112797.

Conesa A, Gotz S, Garcia-Gomez JM, Terol J, Talon M, Robles M. 2005. Blast2GO: a universal tool for annotation, visualization and analysis in functional genomics research. Bioinformatics 21:3674-3676 DOI 10.1093/bioinformatics/bti610.

Cosson J. 2004. The ionic and osmotic factors controlling motility of fish spermatozoa. Aquaculture International 12:69-85 DOI 10.1023/B:AQUI.0000017189.44263.bc.

Cosson J, Groison AL, Suquet M, Fauvel C, Dreanno C, Billard R. 2008. Studying sperm motility in marine fish: an overview on the state of the art. Journal of Applied Ichthyology 24:460-486 DOI 10.1111/j.1439-0426.2008.01151.x.

de Lamirande E, Jiang H, Zini A, Kodama H, Gagnon C. 1997. Reactive oxygen species and sperm physiology. Reviews of Reproduction 2:48-54 DOI 10.1530/ror.0.0020048.

Diouf K, Guilhaumon F, Aliaume C, Ndiaye P, Do Chi T, Panfili J. 2009. Effects of the environment on fish juvenile growth in West African stressful estuaries. Estuarine Coastal and Shelf Science 83:115-125 DOI 10.1016/j.ecss.2009.02.031.

Dorts J, Grenouillet G, Douxfils J, Mandiki SNM, Milla S, Silvestre F, Kestemont P. 2012. Evidence that elevated water temperature affects the reproductive physiology of the European bullhead Cottus gobio. Fish Physiology and Biochemistry 38:389-399 DOI 10.1007/s10695-011-9515-y.

Evans TG, Somero GN. 2008. A microarray-based transcriptomic time-course of hyper- and hypo-osmotic stress signaling events in the euryhaline fish Gillichthys mirabilis: osmosensors to effectors. Journal of Experimental Biology 211:3636-3649 DOI 10.1242/jeb.022160.

Fardilha M, Ferreira M, Pelech S, Vieira S, Rebelo S, Korrodi-Gregorio L, Sousa M, Barros A, Silva V, da Cruz e Silva OA, da Cruz e Silva EF. 2013. “Omics” of human sperm: profiling protein phosphatases. Omics 17:460-472 DOI 10.1089/omi.2012.0119.

Fauvel C, Suquet M, Cosson J. 2010. Evaluation of fish sperm quality. Journal of Applied Ichthyology 26:636-643 DOI 10.1111/j.1439-0426.2010.01529.x.

Gauthier SY, Scotter AJ, Lin F-H, Baardsnes J, Fletcher GL, Davies PL. 2008. A re-evaluation of the role of type IV antifreeze protein. Cryobiology 57:292-296 DOI 10.1016/j.cryobiol.2008.10.122.

Gracey AY. 2007. Interpreting physiological responses to environmental change through gene expression profiling. The Journal of Experimental Biology 210:1584-1592 DOI 10.1242/jeb.004333.

Gueye M, Tine M, Kantoussan J, Ndiaye P, Thiaw OT, Albaret J-J. 2012. Comparative analysis of reproductive traits in black-chinned tilapia females from various coastal, marine, estuarine and freshwater ecosystems. PLoS ONE 7:e29464 DOI 10.1371/journal.pone.0029464.

Havird JC, Henry RP, Wilson AE. 2013. Altered expression of $\mathrm{Na}(+) / \mathrm{K}(+)$-ATPase and other osmoregulatory genes in the gills of euryhaline animals in response to salinity transfer: a meta-analysis of 59 quantitative PCR studies over 10 years. Comparative Biochemistry and Physiology Part D: Genomics \& Proteomics 8:131-140.

Hofmann GE, Todgham AE. 2010. Living in the now: physiological mechanisms to tolerate a rapidly changing environment. Annual Review of Physiology 72:127-145 DOI 10.1146/annurev-physiol-021909-135900. 
Huitorel P, Audebert S, White D, Cosson J, Gagnon C. 1999. Role of tubulin epitopes in the regulation of flagellar motility. In: Gagnon $\mathrm{C}$, ed. The male gamete: from basic science to clinical applications. Vienna, IL: Cache River Press, 475-491.

Lahnsteiner F, Berger B, Weismann T, Patzner RA. 1998. Determination of semen quality of the rainbow trout, Oncorhynchus mykiss, by sperm motility, seminal plasma parameters, and spermatozoal metabolism. Aquaculture 163:163-181 DOI 10.1016/S0044-8486(98)00243-9.

Larsen PF, Nielsen EE, Williams TD, Hemmer-Hansen J, Chipman JK, Kruhoffer M, Gronkjaer P, George SG, Dyrskjot L, Loeschcke V. 2007. Adaptive differences in gene expression in European flounder (Platichthys flesus). Molecular Ecology 16:4674-4683 DOI 10.1111/j.1365-294X.2007.03530.x.

Lazarou M, Thorburn DR, Ryan MT, McKenzie M. 2009. Assembly of mitochondrial complex I and defects in disease. Biochimica Et Biophysica Acta-Molecular Cell Research 1793:78-88 DOI 10.1016/j.bbamcr.2008.04.015.

Lee JK, Kim YJ, Park KS, Shin SC, Kim HJ, Song YH, Park H. 2011. Molecular and comparative analyses of type IV antifreeze proteins (AFPIVs) from two Antarctic fishes, Pleuragramma antarcticum and Notothenia coriiceps. Comparative Biochemistry and Physiology B-Biochemistry \& Molecular Biology 159:197-205 DOI 10.1016/j.cbpb.2011.04.006.

Legendre M, Cosson J, Hadi Alavi SM, Linhart O. 2008. Activation of sperm motility in the euryhaline tilapia Sarotherodon melanotheron heudelotii (Dumeril, 1859) acclimatized to fresh, sea and hypersaline waters. Cybium 32:181-182.

Liu JX, Zhai YH, Gui JF. 2009. Molecular characterization and expression pattern of AFPIV during embryogenesis in gibel carp (Carassius auratus gibelio). Molecular Biology Reports 36:2011-2018 DOI 10.1007/s11033-008-9412-3.

Loeffen JLCM, Triepels RH, Van den Heuvel LP, Schuelke M, Buskens CAF, Smeets RJP, Trijbels JMF, Smeitink JAM. 1998. cDNA of eight nuclear encoded subunits of NADH:ubiquinone oxidoreductase: human complex I cDNA characterization completed. Biochemical and Biophysical Research Communications 253:415-422 DOI 10.1006/bbrc.1998.9786.

Loftus SJ, Crawford DL. 2013. Interindividual variation in complex I activity in Fundulus heteroclitus along a steep thermocline. Physiological and Biochemical Zoology 86:82-91 DOI 10.1086/668850.

Lorin-Nebel C, Avarre JC, Faivre N, Wallon S, Charmantier G, Durand JD. 2012. Osmoregulatory strategies in natural populations of the black-chinned tilapia Sarotherodon melanotheron exposed to extreme salinities in West African estuaries. Journal of Comparative Physiology B-Biochemical Systemic and Environmental Physiology 182:771-780 DOI 10.1007/s00360-012-0657-8.

Maranzana E, Barbero G, Falasca AI, Lenaz G, Genova ML. 2013. Mitochondrial respiratory supercomplex association limits production of reactive oxygen species from complex I. Antioxidants \& Redox Signaling 19:1469-1480 DOI 10.1089/ars.2012.4845.

Marchler-Bauer A, Bryant SH. 2004. CD-Search: protein domain annotations on the fly. Nucleic Acids Research 32:W327-W331 DOI 10.1093/nar/gkh454.

Marshall WS, Ossum CG, Hoffmann EK. 2005. Hypotonic shock mediation by p38 MAPK, JNK, PKC, FAK, OSR1 and SPAK in osmosensing chloride secreting cells of killifish opercular epithelium. Journal of Experimental Biology 208:1063-1077 DOI 10.1242/jeb.01491.

Mochida K, Matsubara T, Andoh T, Ura K, Adachi S, Yamauchi K. 2002. A novel seminal plasma glycoprotein of a teleost, the Nile tilapia (Oreochromis niloticus), contains a partial von Willebrand factor type D domain and a zona pellucida-like domain. Molecular Reproduction and Development 62:57-68 DOI 10.1002/mrd.10071. 
Morita M, Nakajima A, Takemura A, Okuno M. 2011. Involvement of redox- and phosphorylation-dependent pathways in osmotic adaptation in sperm cells of euryhaline tilapia. Journal of Experimental Biology 214:2096-2104 DOI 10.1242/jeb.053405.

Morita M, Takemura A, Okuno M. 2004. Acclimation of sperm motility apparatus in seawater-acclimated euryhaline tilapia Oreochromis mossambicus. Journal of Experimental Biology 207:337-345 DOI 10.1242/jeb.00748.

Oleksiak MF, Churchill GA, Crawford DL. 2002. Variation in gene expression within and among natural populations. Nature Genetics 32:261-266 DOI 10.1038/ng983.

Pagès J, Citeau J. 1990. Rainfall and salinity of a sahelian estuary between 1927 and 1987. Journal of Hydrology 113:325-341 DOI 10.1016/0022-1694(90)90182-W.

Panfili J, Mbow A, Durand JD, Diop K, Diouf K, Thior D, Ndiaye P, Lae R. 2004. Influence of salinity on the life-history traits of the West African black-chinned tilapia (Sarotherodon melanotheron): comparison between the Gambia and Saloum estuaries. Aquatic Living Resources 17:65-74 DOI 10.1051/alr:2004002.

Panfili J, Thior D, Ecoutin JM, Ndiaye P, Albaret JJ. 2006. Influence of salinity on the size at maturity for fish species reproducing in contrasting West African estuaries. Journal of Fish Biology 69:95-113 DOI 10.1111/j.1095-8649.2006.01069.x.

Pfaffl MW. 2001. A new mathematical model for relative quantification in real-time RT-PCR. Nucleic Acids Research 29:e45 DOI 10.1093/nar/29.9.e45.

Piersma T, Drent J. 2003. Phenotypic flexibility and the evolution of organismal design. Trends in Ecology \& Evolution 18:228-233 DOI 10.1016/S0169-5347(03)00036-3.

Piomboni P, Focarelli R, Stendardi A, Ferramosca A, Zara V. 2012. The role of mitochondria in energy production for human sperm motility. International Journal of Andrology 35:109-124 DOI 10.1111/j.1365-2605.2011.01218.x.

Prathalingam NS, Holt WV, Revell SG, Mirczuk S, Fleck RA, Watson PF. 2006. Impact of antifreeze proteins and antifreeze glycoproteins on bovine sperm during freeze-thaw. Theriogenology 66:1894-1900 DOI 10.1016/j.theriogenology.2006.04.041.

Rathburn CK, Sharp NJ, Ryan JC, Neely MG, Cook M, Chapman RW, Burnett LE, Burnett KG. 2013. Transcriptomic responses of juvenile Pacific whiteleg shrimp, Litopenaeus vannamei, to hypoxia and hypercapnic hypoxia. Physiological Genomics 45:794-807 DOI 10.1152/physiolgenomics.00043.2013.

Ruiz-Pesini E, Diez C, Lapena AC, Perez-Martos A, Montoya J, Alvarez E, Arenas J, Lopez-Perez MJ. 1998. Correlation of sperm motility with mitochondrial enzymatic activities. Clinical Chemistry 44:1616-1620.

Savenije HHG, Pages J. 1992. Hypersalinity — a dramatic change in the hydrology of sahelian estuaries. Journal of Hydrology 135:157-174 DOI 10.1016/0022-1694(92)90087-C.

Shaliutina A, Gazo I, Cosson J, Linhart O. 2014. Comparison of oxidant and antioxidant status of seminal plasma and spermatozoa of several fish species. Czech Journal of Animal Science In press.

Shi YG. 2009. Serine/threonine phosphatases: mechanism through structure. Cell 139:468-484 DOI 10.1016/j.cell.2009.10.006.

Tiedke J, Thiel R, Burmester T. 2014. Molecular response of estuarine fish to hypoxia: a comparative study with ruffe and flounder from field and laboratory. PLoS ONE 9:e90778 DOI 10.1371/journal.pone.0090778. 
Tiersch TR, Yang HP. 2012. Environmental salinity-induced shifts in sperm motility activation in Fundulus grandis. Aquaculture 324:145-150 DOI 10.1016/j.aquaculture.2011.10.023.

Tine M, Bonhomme F, McKenzie DJ, Durand J-D. 2010. Differential expression of the heat shock protein Hsp70 in natural populations of the tilapia, Sarotherodon melanotheron, acclimatised to a range of environmental salinities. BMC Ecology 10:11-11 DOI 10.1186/1472-6785-10-11.

Tine M, de Lorgeril J, D’Cotta H, Pepey E, Bonhomme F, Baroiller JF, Durand JD. 2008. Transcriptional responses of the black-chinned tilapia Sarotherodon melanotheron to salinity extremes. Marine Genomics 1:37-46 DOI 10.1016/j.margen.2008.06.001.

Tine M, Guinand B, Durand JD. 2012. Variation in gene expression along a salinity gradient in wild populations of the euryhaline black-chinned tilapia Sarotherodon melanotheron. Journal of Fish Biology 80:785-801 DOI 10.1111/j.1095-8649.2012.03220.x.

Tine M, McKenzie DJ, Bonhomme F, Durand J-D. 2011. Salinity-related variation in gene expression in wild populations of the black-chinned tilapia from various West African coastal marine, estuarine and freshwater habitats. Estuarine Coastal and Shelf Science 91:102-109 DOI 10.1016/j.ecss.2010.10.015.

Tingaud-Sequeira A, Chauvigne F, Lozano J, Agulleiro M, Asensio E, Cerda J. 2009. New insights into molecular pathways associated with flatfish ovarian development and atresia revealed by transcriptional analysis. BMC Genomics 10:434 DOI 10.1186/1471-2164-10-434.

Vandesompele J, De Preter K, Pattyn F, Poppe B, Van Roy N, De Paepe A, Speleman F. 2002. Accurate normalization of real-time quantitative RT-PCR data by geometric averaging of multiple internal control genes. Genome Biology 3:research0034-research003411 DOI 10.1186/gb-2002-3-7-research0034.

Watson ML, Zinn AR, Inoue N, Hess KD, Cobb J, Handel MA, Halaban R, Duchene CC, Albright GM, Moreadith RW. 1998. Identification of morc (microrchidia), a mutation that results in arrest of spermatogenesis at an early meiotic stage in the mouse. Proceedings of the National Academy of Sciences of the United States of America 95:14361-14366 DOI 10.1073/pnas.95.24.14361.

West-Eberhard MJ. 2003. Developmental plasticity and evolution. Oxford: Oxford University Press.

Whitehead A, Crawford DL. 2005. Variation in tissue-specific gene expression among natural populations. Genome Biology 6:R13 DOI 10.1186/gb-2005-6-2-r13.

Whitehead A, Crawford DL. 2006. Neutral and adaptive variation in gene expression. Proceedings of the National Academy of Sciences of the United States of America 103:5425-5430 DOI 10.1073/pnas.0507648103.

Whitehead A, Roach JL, Zhang S, Galvez F. 2011. Genomic mechanisms of evolved physiological plasticity in killifish distributed along an environmental salinity gradient. Proceedings of the National Academy of Sciences of the United States of America 108:6193-6198 DOI 10.1073/pnas.1017542108.

Whiterod NR, Walker KF. 2006. Will rising salinity in the Murray-Darling Basin affect common carp (Cyprinus carpio L.)? Marine and Freshwater Research 57:817-823 DOI 10.1071/MF06021.

Yamaguchi S, Miura C, Kikuchi K, Celino FT, Agusa T, Tanabe S, Miura T. 2009. Zinc is an essential trace element for spermatogenesis. Proceedings of the National Academy of Sciences of the United States of America 106:10859-10864 DOI 10.1073/pnas.0900602106. 